\title{
Demographic characteristics of pectus deformities across Turkey
}

\author{
Pektus deformitelerinin Türkiye genelinde demografik özellikleri

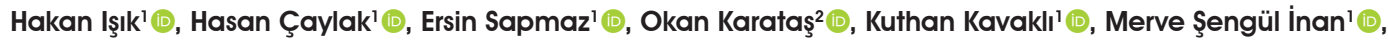 \\ Sedat Gürkök' ${ }^{1}$, Alper Gözübüyük' ${ }^{1}$, Onur Genç ${ }^{1}(\mathbb{1})$ \\ Institution where the research was done: \\ University of Health Sciences, Gülhane Training and Research Hospital, Ankara, Turkey \\ Author Affiliations: \\ 'Department of Thoracic Surgey, University of Health Sciences, Gülhane Training and Research Hospital, Ankara, Turkey \\ 2Department of Thoracic Surgey, Atatürk State Hospital, Sinop, Turkey
}

\begin{abstract}
Background: This study aims to investigate the demographic characteristics and familial inheritance of pectus deformities across Turkey.

Methods: Demographic characteristics of a total of 5,098 patients (5,028 males, 70 females, mean age 23.6 years; range, 1 to 56 years) with pectus excavatum and pectus carinatum admitted to our outpatient clinic between January 1996 and December 2018 were retrospectively analyzed. The distribution of the patients across the country was made according to seven regions and 81 provinces. Familial inheritance was investigated using patients' data obtained from the clinical records and telephone calls.
\end{abstract}

Results: Of all patients, 3,330 (65.3\%) had pectus excavatum and $1,768(34.7 \%)$ had pectus carinatum deformity with a pectus excavatum-to-pectus carinatum ratio of 1/1.9. In the Southeast Anatolia region, the rate of pectus excavatum was lower than the overall average and higher in the Marmara region $(\mathrm{p}=0.009$ and $p=0.037$, respectively). In the Southeast Anatolia region, the rate of pectus carinatum was higher than the general average and lower in the Marmara region ( $\mathrm{p}=0.001$ and $\mathrm{p}=0.003$, respectively). Kastamonu, Çankırı, Karabük, and Sinop were the most common provinces for pectus deformity cases. Family history was positive in $39 \%$ of pectus excavatum and $43 \%$ of pectus carinatum patients. All regions showed a similar distribution in terms of the presence of family history.

Conclusion: This is the first study to report the distribution of pectus deformities in Turkey and the high frequency of pectus deformities in certain regions and provinces of Turkey indicates familial inheritance.

Keywords: Demographic, family history, pectus deformities, pectus excavatum, pectus carinatum, Turkish population.

\section{$\ddot{O} Z$}

Amaç: Bu çalışmada, Türkiye genelinde pektus deformitelerinin demografik özellikleri ve ailesel kalıtımı araştırıld1.

Çalışma planı: Ocak 1996-Aralık 2018 tarihleri arasında polikliniğimize pektus ekskavatum ve pektus karinatum ile başvuran toplam 5098 hastanın (5028 erkek, 70 kadın; ort. yaş 23.6 yıl; dağılım, 2-56 yıl) demografik özellikleri retrospektif olarak incelendi. Yedi bölgeye ve 81 ile göre hastaların ülke genelinde dağılımı yapıldı. Klinik kayıtlardan ve telefon görüşmelerinden elde edilen hasta verileri kullanılarak, ailesel kalıtım araştırıldı.

Bulgular: Hastaların 3330'unda (\%65.3) pektus ekskavatum ve 1768 'inde (\%34.7) pektus karinatum deformitesi olup, pektus ekskavatum-pektus karinatum oranı 1/1.9 idi. Güneydoğu Anadolu bölgesinde pektus ekskavatum oran1, genel ortalamadan daha düşük ve Marmara bölgesinde daha yüksek idi (sırasıyla, $\mathrm{p}=0.009$ ve $\mathrm{p}=0.037$ ). Güneydoğu Anadolu bölgesinde pektus karinatum oranı genel ortalamadan daha yüksek ve Marmara bölgesinde daha düşük idi (sırasıyla, $\mathrm{p}=0.001$ ve $\mathrm{p}=0.003$ ). Kastamonu, Çankırı, Karabük ve Sinop pektus deformiteli olguların en sık karşılaşıldığı iller idi. Pektus ekskavatumlu hastaların \%39'unda ve pektus karinatumlu hastaların \%43'ünde aile öyküsü pozitif idi. Tüm bölgeler aile öyküsü varlığı açısından benzer bir dağılım gösterdi.

Sonuç: Bu çalışma Türkiye'de pektus deformitelerinin dağılımını bildiren ilk çalışma olup, Türkiye'nin bazı bölgeleri ve illerinde pektus deformitelerinin yüksek oranda olması ailesel kalıtımı göstermektedir.

Anahtar sözcükler: Demografik, aile öyküsü, pektus deformiteleri, pektus ekskavatum, pektus karinatum, Türk toplumu.

Received: July 11, 2019 Accepted: December 12, 2019 Published online: April 22, 2020

Correspondence: Ersin Sapmaz, MD. Gülhane Eğitim ve Araşııma Hastanesi Göğüs Cerrahisi Kliniği, 06010 Keçiören, Ankara, Türkiye.

Tel: +90 312 - 3045171 e-mail: esapmaz@hotmail.com

Cite this article as:

Ișı H, Çaylak H, Sapmaz E, Karataș O, Kavaklı K, Şengül Inan M, et al. Demographic characteristics of pectus deformities across Turkey. Turk Gogus Kalp Dama 2020;28(2):322-330 
Chest deformities are common pathologies characterized by different types and levels of depression or protrusion of the sternum and costae. Congenital chest deformities can be divided into main five groups: pectus excavatum (PE), pectus carinatum (PC), Poland syndrome, sternal cleft and defects, and other thoracic deformities. Deformities of PE and PC account for the majority of congenital chest deformities which do not cause severe dysfunction, except for life-threatening rare cases. ${ }^{[1-3]}$

Family history and concomitant other congenital anomalies give rise to thought that these deformities may be more common in a particular population or region. Although there are studies screening student groups of a particular age vary in terms of chest deformities in various cities of Turkey, there is no study on the distribution of pectus deformities across our country by region and province.

Our institution is a central hospital to which military patients are referred across Turkey. It can be speculated that the patient population referred to our hospital is a homogeneous group which reflects the general population of Turkey. In the present study, we aimed to investigate the demographic characteristics and familial inheritance of pectus deformities across Turkey.

\section{PATIENTS AND METHODS}

Patient records with PE and PC admitted to our outpatient clinic between January 1996 and December 2018 were retrospectively analyzed. The patient records between January 2004 and December 2005 (24 months) were unable to be reached due to technical access restrictions for one of the databases. Finally, demographic characteristics of a total of 5,098 patients (5,028 males, 70 females, mean age 23.6 years; range, 1 to 56 years) were included. Pectus cases with other pathologies such as Poland syndrome, arcus deformity, or musculoskeletal deformity and cases with missing hometown data were excluded from the study. In the outpatient clinic system, the data of patients with sufficient data on familial history were used. Data were collected using patient records or telephone calls. The patients were questioned about the presence of chest deformity in their family members, including third-degree relatives. A written informed consent was obtained from each patient. The study protocol was approved by the Gülhane Training and Research Hospital Ethics Committee. The study was conducted in accordance with the principles of the Declaration of Helsinki.

In Turkey, the obligation of military service is only for male individuals. Although there are female patients in the study, the majority of the cases were male patients aged between 20-30 years. This study was designed in our medical center, which is a reference military hospital in Turkey. Therefore, in the pre-military evaluation, patients with a history of surgery due to pectus deformity were included. Patients from all regions of our country were examined at regular intervals in our outpatient clinic to create a homogeneous patient group according to their province of origin.

In order to determine the distribution of cases by provinces and regions, we attempted to standardize the number of patients according to the population density of that province or region. The number of cases with pectus deformity per 100,000 population in the relevant province or region was calculated using the 2018 population data of the Turkish Statistical Institute (TSI). ${ }^{[4]}$

\section{Statistical analysis}

For this descriptive study, we found a country rate for $\mathrm{PE}$ and $\mathrm{PC}$ rates obtained from the study group consisting of all positive cases (PE: 65.3\%, PC: $34.7 \%$ ). We, then, compared the ratios calculated for each region using one sample Z-test for proportion with this general ratio. Multiple correspondence analysis was used to evaluate the patterns of relationships of several categorical dependent variables, such as family history, and frequencies of PE and PC. Statistical comparisons were performed using the nationwide $\mathrm{PE}$ and $\mathrm{PC}$ prevalence rates. Statistical analysis was performed using the IBM SPSS version 25.0 software (IBM Corp., Armonk, NY, USA) and STATA version 16.0 software (StataCorp LLC, TX, USA). Descriptive data were expressed in mean \pm standard deviation $(\mathrm{SD})$, median (min-max) or number and percentage. A $p$ value of $<0.05$ was considered statistically significant.

\section{RESULTS}

Pectus deformities were diagnosed in 5,098 (7.8\%) of a total of 65,827 patients who were admitted to our outpatient clinic throughout the study period (252 months). The distribution of these cases across the country was made according to the current seven regions and 81 provinces. Of the patients with pectus deformity, 3,330 (65.3\%) had PE and 1,768 (34.7\%) had PC. The rate of PE deformity was the highest in the Marmara region (71.8\%) and the rate of PC deformity was the highest in the Southeast Anatolia region (43.6\%). About 50\% of pectus deformities originated from the Black Sea and Central Anatolia regions, accounting for $26 \%$ of the country population. On the other hand, $30 \%$ of the cases originated from 
the Aegean, Marmara, and Mediterranean regions, accounting for $57 \%$ of the country population (Table 1).

According to the calculation of the ratio of positive cases to the general population based on the 2018 population data of the TSI, the average rate of pectus deformities across Turkey was calculated as 6.2/100,000. The Black Sea region was the most common region of pectus deformities with a rate of 15.6/100,000 cases, followed by the Central Anatolia region (9.9/100,000) and Eastern Anatolia region $(8.2 / 100,000)$. On the other hand, the Marmara and Aegean regions were the least common regions of pectus deformities with 2.4/100,000 and 3.6/100,000 cases, respectively (Table 1).

According to the region analysis to the general population, the ratio of $\mathrm{PE}$ was found to be lower than the average ratio in the Southeast Anatolia region $(56.4 \%)$ and was higher in the Marmara region $(71.8 \%)$ ( $p=0.009$ and $p=0.037$, respectively). For PC, these two regions were statistically different from the country average. However, in terms of PC, the Southeast Anatolia region (43.6\%) was higher than the general average and was lower in the Marmara region $(28.2 \%)$ $(\mathrm{p}=0.001$ and $\mathrm{p}=0.003$, respectively) (Table 1$)$.

Given the distribution by provinces, Kastamonu, Çankırı, Karabük, Sinop, and Ardahan were the most common provinces for pectus deformity cases. The fact that the prevalence in these provinces (31.8-26.3/100,000) was about four to five-fold of the Turkey's average $(6.2 / 100,000)$ and the other four were close to each other, except for Ardahan (Table 2).

A color map chart of Turkey was created based on the number of pectus deformity cases calculated by the population density of our provinces. Five different tones of red color were used in this chart. The provinces comprising above four-times more cases than the Turkey's average were illustrated with claret red, the provinces comprising above two-times more cases with red, the provinces comprising above one and a half-times more cases with pink, the provinces comprising above (9.3) and below (3.1) $50 \%$ of the average with light pink, and the provinces comprising less than 3.1/100,000 cases with white (Figure 1). Given the color map chart of Turkey, almost all provinces of the Black Sea region along with the northeast provinces of the Central Anatolia region and the northwest provinces of the East Anatolia region had the highest deformity rates. However, a density area was determined in a separate region consisting of Afyonkarahisar, Burdur, and Isparta provinces in the eastern part of the Aegean region and the northwestern part of the Mediterranean region (Figure 1).

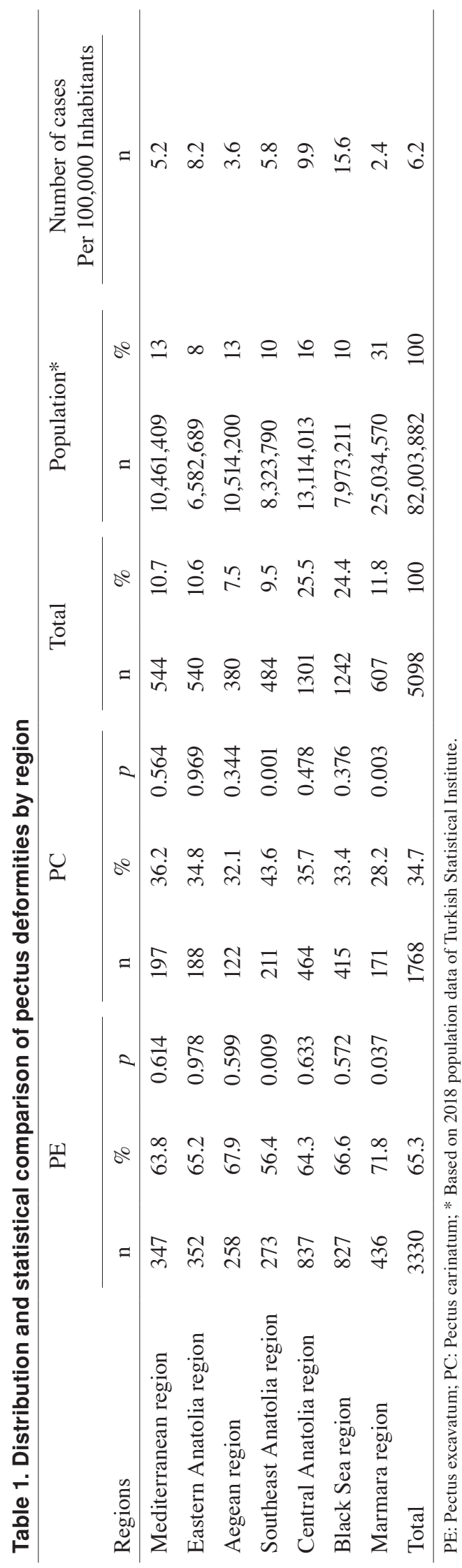


Table 2. Distribution of pectus deformities by provinces (number of cases per 100,000 inhabitants)

\begin{tabular}{|c|c|c|c|c|c|c|c|}
\hline No & Region code* & Province & $* \mathrm{PE}$ & $* \mathrm{PC}$ & $\begin{array}{c}\text { Total number of } \\
\text { deformities }\end{array}$ & Population & $\begin{array}{c}\text { Number of cases } \\
\text { per } 100,000 \text { inhabitants }\end{array}$ \\
\hline 1 & B & Kastamonu & 80 & 42 & 122 & 383,373 & 31.8 \\
\hline 2 & $\mathrm{C}$ & Çankırı & 47 & 20 & 67 & 216,362 & 31.0 \\
\hline 3 & $\mathrm{~B}$ & Karabük & 46 & 21 & 67 & 248,014 & 27.0 \\
\hline 4 & B & Sinop & 40 & 19 & 59 & 219,733 & 26.9 \\
\hline 5 & $\mathrm{E}$ & Ardahan & 20 & 6 & 26 & 98,907 & 26.3 \\
\hline 6 & $\mathrm{C}$ & Kırıkkale & 43 & 28 & 71 & 286,602 & 24.8 \\
\hline 7 & $\mathrm{C}$ & Yozgat & 69 & 33 & 102 & 424,981 & 24.0 \\
\hline 8 & $\mathrm{~B}$ & Zonguldak & 102 & 39 & 141 & 599,698 & 23.5 \\
\hline 9 & $\mathrm{~B}$ & Çorum & 73 & 44 & 117 & 536,483 & 21.8 \\
\hline 10 & B & Rize & 50 & 16 & 66 & 348,608 & 18.9 \\
\hline 11 & $\mathrm{C}$ & Kırşehir & 30 & 15 & 45 & 241,868 & 18.6 \\
\hline 12 & $\mathrm{~B}$ & Bartın & 20 & 16 & 36 & 198,999 & 18.1 \\
\hline 13 & $\mathrm{C}$ & Sivas & 62 & 45 & 107 & 646,608 & 16.5 \\
\hline 14 & $\mathrm{~B}$ & Amasya & 32 & 23 & 55 & 337,508 & 16.3 \\
\hline 15 & $\mathrm{E}$ & Tunceli & 10 & 3 & 13 & 88,198 & 14.7 \\
\hline 16 & $\mathrm{~B}$ & Tokat & 50 & 33 & 83 & 612,646 & 13.5 \\
\hline 17 & B & Ordu & 67 & 33 & 100 & 771,932 & 13.0 \\
\hline 18 & B & Bolu & 25 & 15 & 40 & 311,810 & 12.8 \\
\hline 19 & $\mathrm{E}$ & Kars & 24 & 13 & 37 & 288,878 & 12.8 \\
\hline 20 & $\mathrm{~B}$ & Samsun & 99 & 57 & 156 & $1,335,716$ & 11.7 \\
\hline 21 & $\mathrm{~B}$ & Artvin & 17 & 3 & 20 & 174,010 & 11.5 \\
\hline 22 & $\mathrm{C}$ & Nevşehir & 26 & 8 & 34 & 298,339 & 11.4 \\
\hline 23 & A & Afyon & 54 & 27 & 81 & 725,568 & 11.2 \\
\hline 24 & $\mathrm{~B}$ & Gümüşhane & 13 & 5 & 18 & 162,748 & 11.1 \\
\hline 25 & $\mathrm{E}$ & Muş & 26 & 19 & 45 & 407,992 & 11.0 \\
\hline 26 & B & Trabzon & 64 & 24 & 88 & 807,903 & 10.9 \\
\hline 27 & $\mathrm{~B}$ & Giresun & 35 & 14 & 49 & 453,912 & 10.8 \\
\hline 28 & $\mathrm{E}$ & Erzincan & 16 & 9 & 25 & 236,034 & 10.6 \\
\hline 29 & $\mathrm{E}$ & Erzurum & 52 & 29 & 81 & 767,848 & 10.5 \\
\hline 30 & $\mathrm{Md}$ & Burdur & 18 & 8 & 26 & 269,926 & 9.6 \\
\hline 31 & Md & Isparta & 29 & 13 & 42 & 441,412 & 9.5 \\
\hline 32 & $\mathrm{C}$ & Aksaray & 28 & 11 & 39 & 412,172 & 9.5 \\
\hline 33 & $\mathrm{E}$ & Bitlis & 23 & 9 & 32 & 349,396 & 9.2 \\
\hline 34 & $\mathrm{E}$ & Iğdır & 11 & 7 & 18 & 197,456 & 9.1 \\
\hline 35 & $\mathrm{C}$ & Ankara & 312 & 186 & 498 & $5,503,985$ & 9.0 \\
\hline 36 & $\mathrm{~S}$ & Siirt & 17 & 13 & 30 & 331,670 & 9.0 \\
\hline 37 & A & Kütahya & 28 & 24 & 52 & 577,941 & 9.0 \\
\hline 38 & $\mathrm{~S}$ & Adiyaman & 31 & 24 & 55 & 624,513 & 8.8 \\
\hline 39 & $\mathrm{~S}$ & Batman & 29 & 19 & 48 & 599,103 & 8.0 \\
\hline 40 & $\mathrm{~S}$ & Mardin & 36 & 30 & 66 & 829,195 & 8.0 \\
\hline 41 & A & Uşak & 24 & 4 & 28 & 367,514 & 7.6 \\
\hline 42 & $\mathrm{Mr}$ & Edirne & 27 & 4 & 31 & 411,528 & 7.5 \\
\hline 43 & $\mathrm{Md}$ & K. Maraş & 44 & 41 & 85 & $1,144,851$ & 7.4 \\
\hline
\end{tabular}


Table 2. Continues

\begin{tabular}{|c|c|c|c|c|c|c|c|}
\hline No & Region code* & Province & $* \mathrm{PE}$ & $* \mathrm{PC}$ & $\begin{array}{c}\text { Total number of } \\
\text { deformities }\end{array}$ & Population & $\begin{array}{c}\text { Number of cases } \\
\text { per } 100,000 \text { inhabitants }\end{array}$ \\
\hline 44 & $\mathrm{C}$ & Niğde & 18 & 9 & 27 & 364,707 & 7.4 \\
\hline 45 & $\mathrm{C}$ & Kayseri & 64 & 32 & 96 & $1,389,680$ & 6.9 \\
\hline 46 & $\mathrm{E}$ & Malatya & 42 & 13 & 55 & 797,036 & 6.9 \\
\hline 47 & $\mathrm{C}$ & Konya & 90 & 55 & 145 & $2,205,609$ & 6.6 \\
\hline 48 & $\mathrm{E}$ & Van & 42 & 30 & 72 & $1,123,784$ & 6.4 \\
\hline 49 & $\mathrm{E}$ & 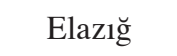 & 21 & 17 & 38 & 595,638 & 6.4 \\
\hline 50 & $\mathrm{C}$ & Karaman & 11 & 5 & 16 & 251,913 & 6.4 \\
\hline 51 & $\mathrm{~S}$ & Kilis & 4 & 5 & 9 & 142,541 & 6.3 \\
\hline 52 & $\mathrm{E}$ & Ağr1 & 20 & 14 & 34 & 539,657 & 6.3 \\
\hline 53 & $\mathrm{C}$ & Eskişehir & 37 & 17 & 54 & 871,187 & 6.2 \\
\hline 54 & B & Bayburt & 2 & 3 & 5 & 82,274 & 6.1 \\
\hline 55 & $\mathrm{E}$ & Bingöl & 14 & 3 & 17 & 281,205 & 6.0 \\
\hline 56 & $\mathrm{E}$ & Hakkâri & 14 & 3 & 17 & 286,470 & 5.9 \\
\hline 57 & $\mathrm{~S}$ & Diyarbakır & 58 & 44 & 102 & $1,732,396$ & 5.9 \\
\hline 58 & $\mathrm{Mr}$ & Kırklareli & 14 & 7 & 21 & 360,860 & 5.8 \\
\hline 59 & $\mathrm{Md}$ & Osmaniye & 18 & 13 & 31 & 534,415 & 5.8 \\
\hline 60 & $\mathrm{E}$ & Şırnak & 17 & 13 & 30 & 524,190 & 5.7 \\
\hline 61 & $\mathrm{Md}$ & Adana & 82 & 33 & 115 & $2,220,125$ & 5.2 \\
\hline 62 & $\mathrm{~B}$ & Düzce & 12 & 8 & 20 & 387,844 & 5.2 \\
\hline 63 & $\mathrm{Md}$ & Mersin & 59 & 27 & 86 & $1,814,468$ & 4.7 \\
\hline 64 & $\mathrm{~S}$ & Şanlıurfa & 46 & 49 & 95 & $2,035,809$ & 4.7 \\
\hline 65 & $\mathrm{Md}$ & Hatay & 49 & 26 & 75 & $1,609,856$ & 4.7 \\
\hline 66 & A & Manisa & 39 & 23 & 62 & $1,429,643$ & 4.3 \\
\hline 67 & $\mathrm{Mr}$ & Balıkesir & 38 & 13 & 51 & $1,226,575$ & 4.2 \\
\hline 68 & $\mathrm{Mr}$ & Çanakkale & 16 & 6 & 22 & 540,662 & 4.1 \\
\hline 69 & $\mathrm{~S}$ & Gaziantep & 52 & 27 & 79 & $2,028,563$ & 3.9 \\
\hline 70 & $\mathrm{Mr}$ & Sakarya & 30 & 9 & 39 & $1,010,700$ & 3.9 \\
\hline 71 & $\mathrm{Md}$ & Antalya & 48 & 36 & 84 & $2,426,356$ & 3.5 \\
\hline 72 & $\mathrm{Mr}$ & Bursa & 66 & 30 & 96 & $2,994,521$ & 3.2 \\
\hline 73 & $\mathrm{Mr}$ & Bilecik & 7 & 0 & 7 & 223,448 & 3.1 \\
\hline 74 & $\mathrm{Mr}$ & Kocaeli & 31 & 16 & 47 & $1,906,391$ & 2.5 \\
\hline 75 & A & Denizli & 16 & 9 & 25 & $1,027,782$ & 2.4 \\
\hline 76 & A & İzmir & 67 & 25 & 92 & $4,320,519$ & 2.1 \\
\hline 77 & $\mathrm{Mr}$ & Tekirdağ & 12 & 9 & 21 & $1,029,927$ & 2.0 \\
\hline 78 & A & Muğla & 15 & 4 & 19 & 967,487 & 2.0 \\
\hline 79 & A & Aydın & 15 & 6 & 21 & $1,097,746$ & 1.9 \\
\hline 80 & $\mathrm{Mr}$ & İstanbul & 194 & 76 & 270 & $15,067,724$ & 1.8 \\
\hline 81 & $\mathrm{Mr}$ & Yalova & 1 & 1 & 2 & 262,234 & 0.8 \\
\hline Total & & & 3,330 & 1,768 & 5,098 & $82,003,882$ & 6.2 \\
\hline
\end{tabular}

* Region codes; PE: Pectus excavatum; PC: Pectus carinatum; B: Black Sea region; E: Eastern Anatolia region; C: Central Anatolia region; A: Aegean region; Md: Mediterranean region; Mr: Marmara region; S: Southeast Anatolia region. 


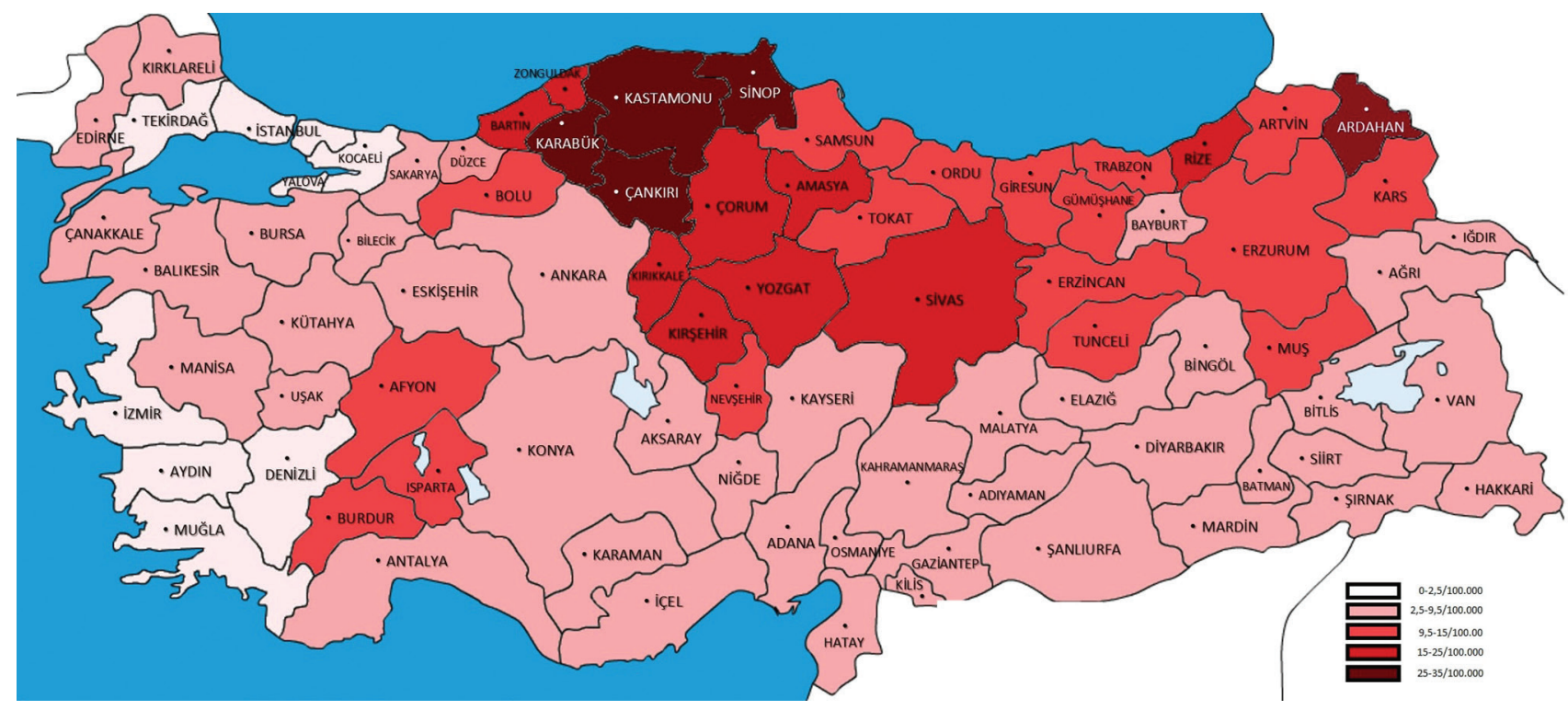

Figure 1. Color scale map based on pectus deformity case rates.

Given the family history in pectus deformities, $1,348(26.4 \%)$ of 5,098 patients with pectus deformity had compölete data in terms of family history characteristics. The data were obtained from medical records in $872(64 \%)$ of 1,348 patients, while family history was able to be obtained via telephone calls in the remaining $476(36 \%)$ patients. Of 1,348 patients

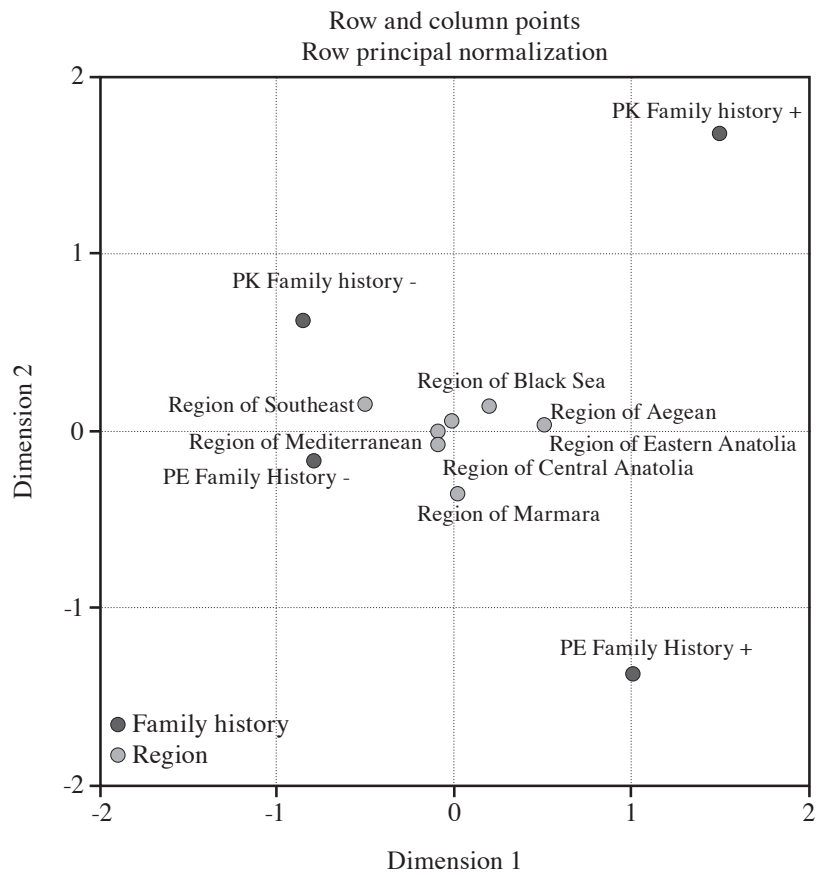

Figure 2. Two-dimensional multiple correspondence analysis graph for PE, PC, and family history.

PE: Pectus excavatum; PC: Pectus carinatum. with complete information on family history, 852 (63\%) had PE and 496 (37\%) had PC deformity. A total of $329(39 \%)$ of 852 patients with PE deformity and $215(43 \%)$ of 496 patients with PC deformity had a positive family history. Considering both deformities together, a positive family history was found in 544 (40\%) of 1,384 cases. Given the distribution of the cases with a positive family history by region, it was remarkable that the Aegean region had significantly high rates $(66 \%$ and $64 \%$, respectively) for both $\mathrm{PE}$ and $\mathrm{PC}$ deformity, while in the Southeast Anatolia region had the lower rates (13\% and $19 \%$, respectively). When the family history between regions was analyzed with the multiple correspondence analysis, there was a close distribution between the regions (Figure 2).

\section{DISCUSSION}

Abnormal distortions in the osseous and cartilaginous structures forming the rib cage due to congenital and acquired causes are defined as chest deformities. Congenital chest deformities do not usually cause severe dysfunction, except for lifethreatening rare cases. Pectus deformities consist of two basic deformities: (i) PE, where the first and second costae are mostly normal and the other costae are displaced posteriorly with the sternum; and (ii) PC, where the sternum is protruded anteriorly. ${ }^{[1-3,5,6]}$

Pectus excavatum is the most common (80 to $90 \%$ ) anterior chest wall deformity, followed by PC with a prevalence of 5 to $20 \%$. In different studies, it has been 
reported that the ratio of $\mathrm{PC} / \mathrm{PE}$ may range between $1: 13$ and $1: 45 \cdot \cdot^{[1-3,6-9]}$ In our study, in contrast with these basic literature data, of pectus deformities, $65.3 \%$ were $\mathrm{PE}, 34.7 \%$ were PC deformities, and the ratio of PC/PE was approximately $1 / 1.9$. In three different studies screening school-age children for chest deformity, two from Turkey and one from Brazil, PE was reported in $76(38 \%)$ of 199 cases, $19(55 \%)$ of 34 cases, and $14(54 \%)$ of 26 cases, respectively. ${ }^{[10-12]}$ Taken together, these results indicate that PE deformity is the most common anterior chest wall deformity; however, the ratio of $\mathrm{PC} / \mathrm{PE}$ is around 1:2 for our country.

The incidence of PE deformity is $1 / 300-4,000$ to $1 / 1,000$ births and three to five-times higher in males than in females, and the incidence of PC deformity is $1 / 10,000$ births and four times higher in males..$^{[1,3,6-8,10]}$ In the literature and studies conducted in our country, the prevalence of chest deformity is similar, ranging from 0.7 to $1.4 \%$. $^{[1-15]}$

There are screening studies including school children to determine the prevalence of pectus deformities. In the research by Akkas et al. ${ }^{[1]}$ including 14,108 students aged between 11 and 14 years in Ankara province, the rate of chest deformity was found to be $1.41 \%$. Therefore, studies conducted by adhering only to a particular province may produce misleading results. Considering this issue, we believe that our study would be a guide for future research.

Pectus deformities may coexist with some other congenital anomalies. Scoliosis, congenital heart disease, asthma, and Marfan syndrome are among the most common concomitant anomalies. It has been reported that scoliosis is found in 15 to $26 \%$ of patients with PE deformity and in 10 to $12 \%$ and $21 \%$ of patients with PC deformity; asthma and congenital heart diseases are more common in these patients than in normal population. In addition to these anomalies, the coexistence of PE and chromosomal anomalies such as Prune-Belly syndrome, myopathies, and Turner syndrome has been reported..$^{[1,3,9,16,17]}$

Our country is divided into seven different geographical regions. Although the Black Sea region comprising 18 provinces includes $10 \%$ of the entire Turkish population, the majority of pectus cases as much as $24 \%$ (1,242 cases) originate from this region. This corresponds to about 2.5-fold of the Turkey's average $(6.2 / 100,000)$ with 15.6 deformity cases per 100,000 individuals. Although the Black Sea region is followed by the Central Anatolia region with 9.9 cases per 100,000 individuals, the East Anatolia region with 8.2 cases per 100,000 individuals and they appear to be above the Turkey's average, they fall behind compared to the Black Sea region in terms of case density.

In our study, since the entire population was not scanned for the presence of pectus deformity, the ratio of pectus deformity-positive cases in each region was compared with the total average rate. Accordingly, the PE ratio was found to be lower in the Southeast Anatolia region than the country average (56.4\%) and higher in the Marmara region $(71.8 \%)(\mathrm{p}=0.009$ and $\mathrm{p}=0.037$, respectively). Conversely, the ratio of PC was higher in the Southeast Anatolia region (43.6\%) than in the general average and lower in the Marmara region $(28.2 \%)(\mathrm{p}=0.001$ and $\mathrm{p}=0.003$, respectively). The prevalence we obtained can be considered to constitute only half of the population, as approximately $99 \%$ of the patients in our study consisted of male patients. The true prevalence should be approximately twotimes more than the given rates.

Given the distribution by provinces, Kastamonu, Çankırı, Karabük and Sinop, which are adjacent to each other, seem to have four to five-teams higher density (26.9-31.8/100,000) than the Turkey's average $(6.2 / 100,000)$. Ardahan $(26.3 / 100,000)$, which ranks the fifth, draws attention with its close neighborhood with the Black Sea region.

It can be thought that some provinces close to each other in terms of prevalence rates may replace each other over time and small changes may occur in the color map chart of Turkey that we created in our study. However, we observed that a 1.5 to 5-times higher density than the Turkey's average was notable in all Karadeniz provinces, particularly in Kastamonu, Çankırı, Istanbul, Sinop, Zonguldak, and Bartın (except Bayburt) in the data we made before and updated over the years.

Increased familial inheritance is present in pectus deformities. Family history in PE deformity was first described by Erich Ebstein in 1921. Sainsbury reported six cases in four generations in 1947 and Elisberg reported 11 cases in four generations in $1958 .^{[18-20]}$ Currently, it is reported that $37 \%$ of PE cases have an inheritance of chest deformity in one of their family members and this rate is $25 \%$ in PC deformity ${ }^{[1]}$ In the genetic research by Creswick et al. ${ }^{[10]}$ on family history in PE deformity, of 34 families, 14 had autosomal dominant inheritance, four had autosomal recessive inheritance, six had X-linked recessive inheritance, and 10 had complex inheritance patterns, and that mostly multifactorial hereditary characteristics appear to play a role, although Mendelian inheritance may occur. 
In our study, 39\% of PE cases had a family history, which is consistent with the literature. In addition, family history (43\%) was found to be higher in patients with PC compared to the literature data $(25 \%){ }^{[1]}$ It is remarkable that the positive family history reaches up to $65 \%$ in the Aegean region, whereas this rate is $15 \%$ in the Southeast Anatolia region. However, we do not have enough data to discuss the reasons for this which needs to be explained.

In our study, although the number of cases with a positive family history was found to be higher in the cases of Black Sea region, all regions showed a similar distribution in terms of presence of family history according to the multiple correspondence analysis graph. In which region the incidence of familial transmission is higher can be only explained by extensive scanning studies. For the high rate of family history we found in the Black Sea region and some provinces, the first explanations springing to mind may be as follows: the settlements of certain communities in these regions as a result of migrations in the historical process, consanguineous marriages, migrations, socioeconomic and nutritional factors in this disease, which may exhibit family history. Based on these data, it is necessary to investigate additional topics such as the rate of other congenital anomalies that may be seen with pectus deformity in these regions and provinces or the presence of a similar family history.

In our study, there are certain limitations to prevent us to reach some proportional results. Due to being a military hospital, the majority of the patients in the registry system are male patients of a certain age range, and sufficient statistical studies cannot be performed for female patients. Although pectus deformities are not a disease group of a certain age group, age-related deformity incidence rates are unable to be obtained. As the severity of pectus deformities, indications for surgery, patients undergoing surgery do not contribute to the main idea of the article, and these issues are not addressed here.

In conclusion, we believe that our study, which is the first study regarding the distribution of pectus deformity by regions and provinces across Turkey, may be a reference study for future research in terms of prevalence, social characteristics, consanguineous marriages, socioeconomic structure, migrations, and other congenital diseases. Pectus deformities are more frequent in certain regions and our study would shed light on further studies about the reasons of this situation.

\section{Declaration of conflicting interests}

The authors declared no conflicts of interest with respect to the authorship and/or publication of this article.

\section{Funding}

The authors received no financial support for the research and/or authorship of this article.

\section{REFERENCES}

1. Shamberger RC. Chest Wall deformities. In: Shields TW, editor. General Thoracic Surgery. Vol I. 7th ed. Baltimore: Lippincott Williams \& Wilkins; 2009. p. 653-81.

2. Falcoz PE, Olland A, Santelmo N, Massard G. Chest wall deformities. In: Kużdżal J, editor. ESTS Textbook of Thoracic Surgery. Vol II. Kraków: Medycyna Praktyczna; 2015. p. 15-25.

3. Sarper A, Demircan A. Konjenital göğüs duvarı anomalileri. In: Ökten İ, Güngör A, editörler. Göğüs Cerrahisi. Cilt 2. Ankara: Sim Matbaacılık; 2003. p. 701-23.

4. Türkiye İstatistik Kurumu, Temel İstatistikler, Nüfus ve Demografi: Yıllara Göre il Nüfusları. Available at: http:// www.tuik.gov.tr/PreIstatistikTablo.do?istab_id=1590

5. Falcoz PE, Santelmo N, Massard G. Chest Wall Disorders. In: Palange P, Simonds AK, editors. ERS Handbook of respiratory Medicine. 2nd ed. Seffield: European Respiratory Society; 2013. p. 448-50.

6. Fokin AA, Steuerwald NM, Ahrens WA, Allen KE. Anatomical, histologic, and genetic characteristics of congenital chest wall deformities. Semin Thorac Cardiovasc Surg 2009;21:44-57.

7. Kelly RE Jr, Lawson ML, Paidas CN, Hruban RH. Pectus excavatum in a 112-year autopsy series: anatomic findings and the effect on survival. J Pediatr Surg 2005;40:1275-8.

8. Dean C, Etienne D, Hindson D, Matusz P, Tubbs RS, Loukas M. Pectus excavatum (funnel chest): a historical and current prospective. Surg Radiol Anat 2012;34:573-9.

9. Behr CA, Denning NL, Kallis MP, Maloney C, Soffer SZ, Romano-Adesman A, et al. The incidence of Marfan syndrome and cardiac anomalies in patients presenting with pectus deformities. J Pediatr Surg 2019;54:1926-8.

10. Creswick HA, Stacey MW, Kelly RE Jr, Gustin T, Nuss D, Harvey H, et al. Family study of the inheritance of pectus excavatum. J Pediatr Surg 2006;41:1699-703.

11. Akkaş Y, Gülay Peri N, Koçer B, Gülbahar G, Baran Aksakal FN. The prevalence of chest wall deformity in Turkish children. Turk J Med Sci 2018;48:1200-6.

12. Esme H, Bükülmez A, Doğru Ö, Solak O. Prevalence of chest wall deformities in primary school children of Afyon city. Turk Gogus Kalp Dama 2006;14:34-7.

13. Soysal O, Yakıncı C, Durmaz Y. Malatya il merkezindeki ilkokul çağı çocuklarında göğüs duvarı deformitesi prevalansı ve göğüs duvarı deformitelerine genel bakış. Klinik Bilimler \& Doktor 1999;5:382-5.

14. Westphal FL, Lima LC, Lima Neto JC, Chaves AR, Santos Júnior VL, Ferreira BL. Prevalence of pectus carinatum and pectus excavatum in students in the city of Manaus, Brazil. J Bras Pneumol 2009;35:221-6. 
15. Goretsky MJ, Kelly RE Jr, Croitoru D, Nuss D. Chest wall anomalies: pectus excavatum and pectus carinatum. Adolesc Med Clin 2004;15:455-71.

16. Welch KJ, Kraney GP. Abdominal musculature deficiency syndrome prune belly. J Urol 1974;111:693-700.

17. Waters P, Welch K, Micheli LJ, Shamberger R, Hall JE. Scoliosis in children with pectus excavatum and pectus carinatum. J Pediatr Orthop 1989;9:551-6.

18. Ebstein E. Zur geschichte der familiaren trichterbrust. Deutsche Medizinische Wochenschrift 1921;47:1070-1.

19. Sainsbury HS. Congenital funnel chest. Lancet 1947;2:615.

20. Elisberg EI. Electrocardiographic changes associated with pectus excavatum. Ann Intern Med 1958;49:130-41. 